\title{
Assessment of post fire debris flow potential in a Mediterranean type ecosystem
}

\author{
I. D. Mitsopoulos ${ }^{1} \&$ D. Mironidis ${ }^{2}$ \\ ${ }^{1}$ Laboratory of Forest Protection, \\ School of Forestry and Natural Environment, \\ Aristotle University of Thessaloniki Greece \\ ${ }^{2}$ Laboratory of Mountainous Water Management and Control, \\ School of Forestry and Natural Environment, \\ Aristotle University of Thessaloniki Greece
}

\section{Abstract}

The expansion of human development into forested areas has created a situation where wildfires can adversely affect lives and property, as can the flooding and landslides that occur in the aftermath of wildfires. An estimation of post wildfire debris flow activity was determinated in a recently burnt area occupied by typical Mediterranean vegetation. A simple method that measures fire severity was applied and a detailed map of debris flow generation potential was created using a Geographical Information System. The analyses indicates that the area of the basin burned, the area of the basin with slopes greater than or equal to $20 \%$, and fire severity affect debris flow peak discharge. By utilizing this method local land management agencies can develop debris flow specific mitigation efforts to watersheds that are the most prone to extreme fire events.

Keywords: wildfires, debris flow potential, Geographical Information System, Mediterranean ecosystem.

\section{Introduction}

Wildland fires are the most destructive disturbance of the natural lands in the Mediterranean Basin. Mediterranean landscapes have always been subjected to fire, thus burning has became part of their dynamic natural equilibrium [1]. Recent changes in land-use patterns in the Mediterranean Basin have implied the reduction or abandonment of traditional activities, such as extensive grazing or 
wood harvesting, which resulted in the increase of the amount of fuel available for burning [2]. Aleppo pine forests are estimated to cover 2500000 ha and constitute an important part of ecosystems from West to East and North to South of the Mediterranean Basin. These forests are particularly flammable and represent $1 / 3$ of the total burned area in the Mediterranean Basin [3]. During a 17 year period (1980-1996), 11.15\% of the fire events in Greece, burst over Aleppo pine forests, consuming 83410 ha, which are approximately $16 \%$ of the total burned area. On average, $2.85 \%$ of the total Aleppo pine forested area is burnt annually in Greece [4].

Wildland fires can become a critical factor in soil degradation processes, because affects the physico-chemical characteristics of the soil [5], increase surface runoff due to the complete or partial loss of vegetation, increase the water repellency of the surface layers of the soils, reduce water infiltration rates, water storage capacity and soil particle aggregation stability [6]. These effects are due to the destruction of the vegetation cover and litter layer, the creation of a crust of ash deposits on the soil surface, the development of a hydrophobic layer, the alteration of soil texture and the changes in soil physical, chemical and biological properties that are caused by the fires [7]. Burning intensity significantly affects soil erosion processes because it determines the extent of destruction of the vegetation cover, the depth of heat penetration and the temperature gradient into the soil during wildland fires [8]. The loss of plant cover and of litter layer expose the soil to the increased kinetic energy of raindrops, which in turn favour the runoff production, soil detachment, raindrop splash and sediment yield [9]

Debris flows are produced frequently in response to summer convective thunderstorm activity over drainage basins burned by wildfire [10]. Debris flows pose a hazard distinct from other sediment-laden flows because of their unique destructive power; debris flows can occur with little warning and can exert great impulsive loads on objects in their paths. Even small debris flows can strip vegetation, block drain-ageways, damage structures, and endanger human life [11].

The objective of this study was to investigate post fire debris flow potential in a Mediterranean ecosystem dominated by Pinus halepensis Mill. in northern Greece.

\section{Methodology}

\subsection{Study area}

The study area is located at the Kassandra Peninsula in North Greece $\left(25^{\circ} 30^{\prime} \mathrm{E}\right.$ and $40^{\circ} \mathrm{N}$ ) (fig.1). The peninsula has an area of 35000 ha where the Pinus. halepensis forests occupy 40 per cent [12]. The northern part of the peninsula is flat with slight hilly elevation in the western part and mostly with rocky coasts. On the contrary, in the southern part there are alternating hilly elevation with an average height of 150-200 m (maximum of $334 \mathrm{~m}$ ). According to the climatic data from the meteorological station of the Forest Service, the climate of the area 
is of the Mediterranean type with mild winters and dry hot summers. The mean annual rainfall reaches $560 \mathrm{~mm}$, while the mean annual air temperature goes up to $16.5^{\circ} \mathrm{C}$. The ecologically dry period begins in the middle of September. According to the climatic classification of Koeppen [13], the climate of the study area is recorded as the special climatic type Csa and it becomes identical to the type of the intense mid-Mediterranean character of bioclimate of Greece. Geologically, the peninsula belongs to Axios zone. Petrologically, it shows a relative homogeneity since the dominant rocks are marls, cobble sand, marl limestone and only the area of Paliouri cape is occupied by basic pyrogenic rocks [14].

The study site is a forest of Pinus halepensis Mill. (Aleppo pine), 30 years old, with average tree height $10-15 \mathrm{~m}$ and dense canopy closure (80-95\%). The understory vegetation was sparse and the litter layer was thin and fragmented, due to intensive grazing and passed surface, low intensity fires. The basins are located on inclined terrain with generally mild to moderate slopes, steeper in places. The soil types are moderate shallow, rich in skeletal material in all horizons sandy-clay and sandy-clay loam. The soil depth ranged from 10 to 20 $\mathrm{cm}$. The fire occurred on 16 July 2005 . Due to very strong wind (7 BF), fire behavior was erratic. Intensive crowning and spotting was observed, while due to the spatial heterogeneity of fuels and the suppression tactics in the adjacent basin, unburned vegetation was left. Thus, a severely and a moderately burned watersheds were created.
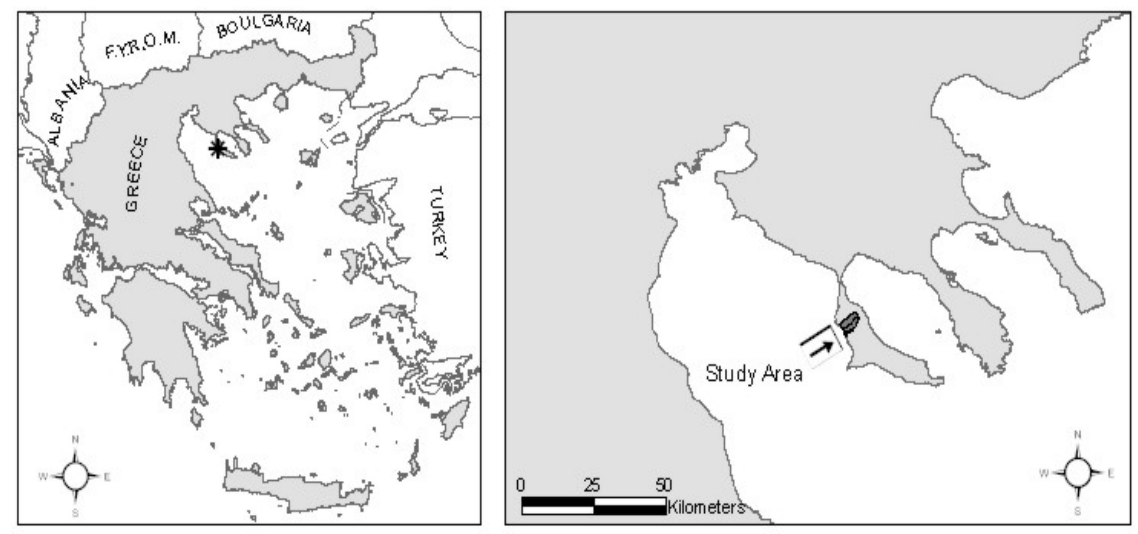

Figure 1: The location of the field area in the Greek territory.

\subsection{Field work}

The visual characteristics of the burned vegetation cover and litter layer were used in order to describe the watershed basins that experienced different burning intensities during the fire, according to methods of Wells et al. [15] and Moreno and Oechel [16].

Canopy closure was assessed with a spherical densiometer during multiple measurements in the watersheds [17]. Branch diameter measured with a small 
scale pachymeter at representative locations. Ocular estimates were used to assess the litter consumption.

Moderate burning conditions: The crown closure left intact by the fire 50$60 \%$. The litter layer was significantly consumed by the fire and the soil surface was severely exposed (70-80\% of the total surface). However, there was charred plant residue at places on the forest floor, fallen from the scorched tree canopy of the overstory. Immediately after the fire, the ash from incinerated litter was inconspicuous and soon disappeared. The average diameter of crown fuels that were left intact by the fire was $0.6 \mathrm{~cm}$.

Severe burning conditions: The litter layer was completely consumed $(>90 \%)$ and an ash layer could be observed at various locations on the surface of the mineral soil. The crown closure was only $10 \%$ and crown fuels with minimum diameter greater than $1.5 \mathrm{~cm}$ were left intact by the fire.

\subsection{GIS analysis}

The watershed areas boundaries of the torrents of the study area were determined by the topographical maps of the Military Geographical Service (range 1:50.000). The digitization of the hydrographic network, the watershed areas boundaries and the contour lines was realized by using Geographical Information Systems. This was followed by the specification of the morphometric and hydrographic features using the ArcGIS 9 program. The digitisation of the contour lines resulted in the Digital Elevation Model, which was then used in order to determine the slopes of the study area.

Information concerning the land cover came from the Satellite data Landsat $\mathrm{TM}$ and remote sensing, while the data extraction for the determination of the types and the areas of the torrential rocky formations was achieved by using geological maps (range 1:50.000) of the Geological and Mineral Research Institute and after the proper digitization and elaboration with G.I.S were applied.

The above actions resulted in the production of three thematic maps in a vector form (Fire severity, slope, Geological support). Afterwards, the module Spatial Analyst of ArcGIS 9 was used so as to convert the above-mentioned maps in a grid form. Moreover, a reclassification of these maps was realized based on the features of each information level and new values to objectives were assigned. The outcome of this series of actions was the division of each level into grid cells, which represent locations and have a value for each map layer. Cells from the three layers stack up on top of each other describing many attributes of each location.

\section{Results}

Table 1 presents a synopsis of the characteristics of the watershed used in this study. The advantage of the study was that the adjacent watersheds had similar soil type, slope, aspect and overstory vegetation, differing only in the severity of burning conditions. This facilitated the comparison among them. 
Table 1: $\quad$ Morphometric characteristics of the drainage basin.

\begin{tabular}{|c|c|c|c|c|c|c|}
\hline Torrent & $\begin{array}{c}\mathrm{F} \\
\left(\mathrm{km}^{2}\right)\end{array}$ & $\begin{array}{c}\mathrm{U} \\
(\mathrm{km})\end{array}$ & $\begin{array}{c}\mathrm{H}_{\min } \\
(\mathrm{m})\end{array}$ & $\begin{array}{c}\mathrm{H}_{\max } \\
(\mathrm{m})\end{array}$ & $\begin{array}{c}\mathrm{H}_{\text {med }} \\
(\mathrm{m})\end{array}$ & $\begin{array}{c}\mathrm{J}_{\mathrm{i}} \\
\%\end{array}$ \\
\hline Drainage basin & 24,98 & 22,93 & 0 & 140 & 64,89 & 14,82 \\
\hline
\end{tabular}

$F$ : Watershed Area, $U$ : Perimeter, $H_{\text {min }}$ : Minimum Elevation of Watershed, $H_{\text {max }}$ : Maximum Elevation of Watershed, $H_{\text {med }}$ : Mean Elevation of Watershed $J_{i}=$ Mean slope of Watershed.

As for the description of the nature in the study area, the following maps have been produced, fig.2: geology, slope, elevation, and fire severity. The maps that will be used for the assessment of the potential post fire debris flow hazard are: slope, geology and fire severity.

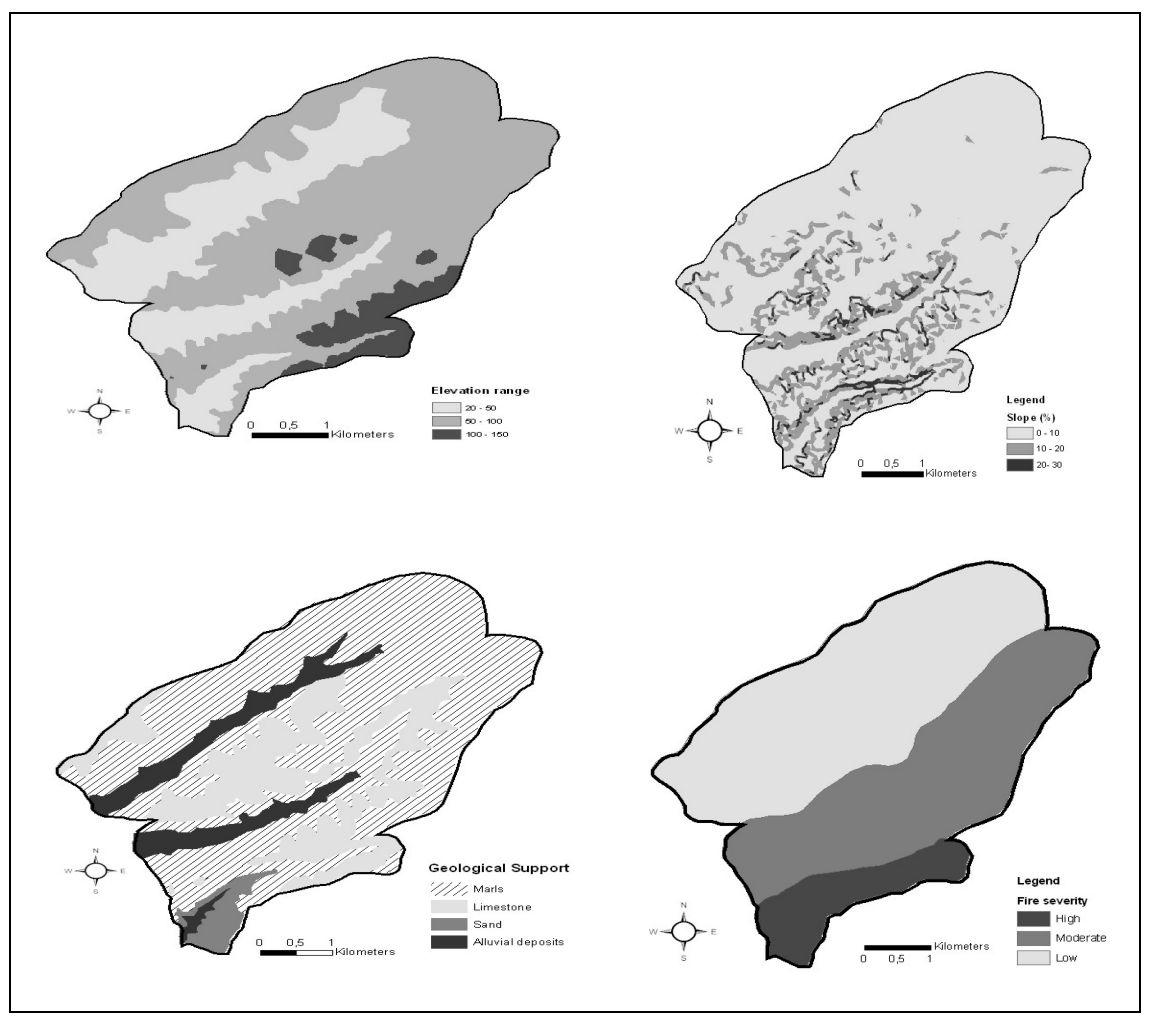

Figure 2: Description of the nature state.

According to field studies that report the causes of debris flow generation in Mediterranean ecosystems [18, 19] the following value factors were applied (Table 2): 
Table 2: $\quad$ Post fire debris flow hazard factor value.

\begin{tabular}{|c|c|}
\hline \multicolumn{2}{|c|}{ Fire severity } \\
\hline Low & 5 \\
\hline Moderate & 10 \\
\hline High & 20 \\
\hline \multicolumn{2}{|c|}{ Slope } \\
\hline $0-10$ & 5 \\
\hline $11-20$ & 10 \\
\hline$>20$ & 20 \\
\hline \multicolumn{2}{|c|}{ Geological support } \\
\hline Marls & 20 \\
\hline Sand & 10 \\
\hline Limestone & 5 \\
\hline Alluvial deposit & 0 \\
\hline
\end{tabular}

Table 3 presents the category rating of post fire debris flow potential.

Table 3: $\quad$ Category rating of post fire debris flow potential.

\begin{tabular}{|c|c|}
\hline Category rating & Value range \\
\hline Low & $0-20$ \\
\hline Moderate & $20-40$ \\
\hline High & $40-60$ \\
\hline
\end{tabular}

From the combination of the three maps of fire severity, slope and geology support and category rating of the factor values the post fire debris flow potential map is obtained using the Spatial Analyst Raster calculator command, which performs map algebra calculation between raster layers (fig.3).

\section{Conclusion}

Fire is a natural and important part of the disturbance regime for forested terrestrial and aquatic systems. Fire effects on hydrological processes and land degradation on a drainage basin or watershed level are related to the effects of ground and vegetation cover destroyed by fire. Wildfire can have profound effects on a drainage basin through the consumption of the rainfall-intercepting canopy and the soil-mantling litter and duff and through the formation of waterrepellent soils. These changes can result in decreased rainfall infiltration into the soil and, subsequently, a significant increase in overland flow and runoff in channels. 


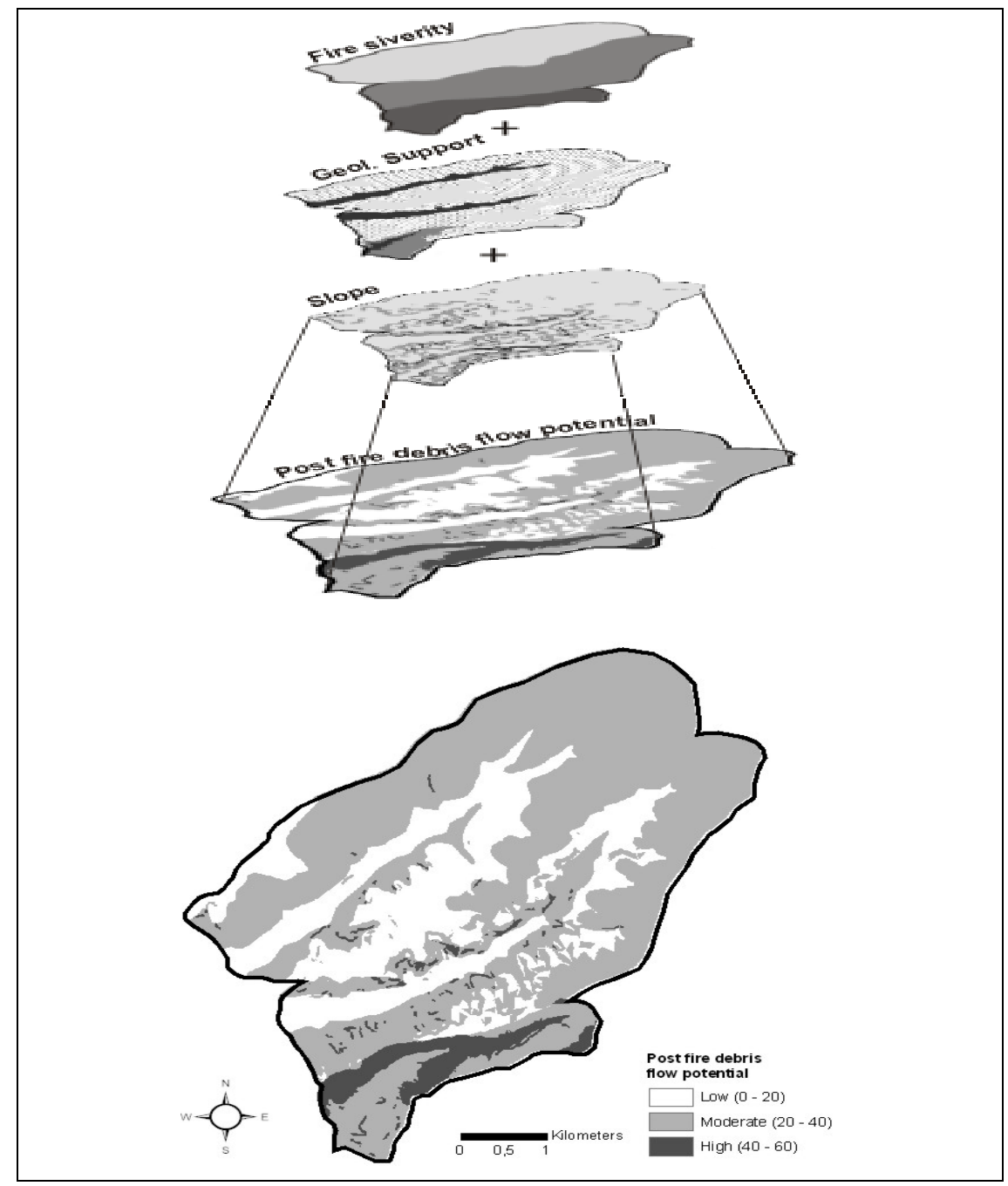

Figure 3: $\quad$ Post fire debris flow potential map.

From post fire debris flow potential map it has become possible the spatial distribution of debris flow hazard. The method developed here will be useful both in pre-fire planning and post-fire response. Application of the method before the occurrence of wildfires can be used to identify sensitive basins and thus serve to direct protection efforts during a fire incident. Post-fire, these maps can be used not only to guide and prioritize post-fire data collection and field mitigation efforts, but also to make effective and appropriate mitigation decisions. Especially in Mediterranean and submediterranean conditions where severe wildfires occur mainly in summer and torrential rainfall events in autumn, management activities including technical and agrotechnical works and 
conservation measures, such as herbaceous seedlings, may contribute to prevent debris flow genesis in the first vegetation regeneration phase after the fire.

\section{References}

[1] Moreno J.M., Oechel W.C., The role of fire in Mediterranean-type ecosystems, Springer-Verlag, New York, 1994.

[2] Perez B., Cruz A., Fernandes-Gonzales F., Moreno J.M., Effects of the recent land-use history on the postfire vegetation of uplands in Central Spain, For. Ecol. Manage. 182 pp. 273-283, 2003

[3] Quezel P., Taxonomy and biogeography of Mediterranean pine species, in: Ne'eman G., Trabaud L. (Eds.), Ecology, Biogeography and Management of Pinus halepensis and Pinus brutia Forest Ecosystems in the Mediterranean Basin. Backhuys Publishers, Leiden, pp. 1-12, 2000.

[4] Dimitrakopoulos A.P., PYROSTAT -- a computer program for forest fire data inventory and analysis in Mediterranean countries, Environmental Modelling and Software 16 pp. 351-359, 2001.

[5] DeBano L.F., D.G. Neary, and P.F. Ffolliott. Fire's Effects on Ecosystems. New York: John Wiley \& Sons. 333 p. 1998.

[6] Inbar, M., Tamir, M. \& Wittenberg, L., Runoff and erosion processes after a forest fire in Mount Carmel, a Mediterranean area, Geomorphology. 24, pp. 17-33, 1998.

[7] DeBano L.F., Water Repellent Soils: A State of the Art. USDA Forest Service, General Technical Report PWS-46, 1981.

[8] Dimitrakopoulos A.P., Seilopoulos D.G., Early post fire soil erosion in Mediterranean ecosystem in Greece. Journal of Balkan Ecology, 4, pp. 5156.2001 .

[9] Shakebsky R.A., Coelho C., Ferreira A.D., Terry J.P., Walsh R., Wildfire impacts on soil erosion and hydrology in wet Mediterranean forest, Portugal. International Journal of Wildland Fire 3, pp. 95-110, 1993.

[10] Cannon, S.H., Debris-flow generation from recently burned drainage basins: Environmental and Engineering Geoscience 7, pp. 321-341, 2001

[11] Cannon, S.H., Powers, P.S., and Savage, W.Z., Fire-related hyperconcentrated and debris flows on Storm King Mountain, Glenwood Springs, Colorado, USA: Environmental Geology 34, pp. 210-218, 1998.

[12] Tsitsoni, T., Conditions determining natural regeneration after wildfires in the Pinus halepensis (Miller, 1768) forests of Kassandra Peninsula (North Greece). Forest Ecology and Management 92, pp. 199-208, 1997.

[13] Critchfield, H. J., General Climatology, 3rd Edition, Prentice Hall Press, 1974.

[14] Mountrakis, M. D., Geology of Greece. University Studio Press, Thessaloniki, p. 207, 1985.

[15] Wells, C.G., Campbell, R.E., DeBano, L.F., Lewis, C.E., Fredickson, R.L., Franklin, E.C., Froelich, R.C., Dunn, P.H., Effects of fire on soils: a state-of-knowledge review. U.S. For. Serv. Gen. Tech. Rep. WO-7, p. 34, 1979. 
[16] Moreno, J. M., Oechel. W. C., A simple method for estimating fire intensity after a burn in California chaparral. Acta Oecologica 10 pp. 5768, 1989.

[17] Lemmon, P. E., A spherical densiometer for estimating forest overstory density. Forestry Science 2, pp. 314-320, 1956.

[18] Emmanouloudis D., Criteria for determining the current activity of torrents in their depositional areas. Symposium for Erosion Debris Flows and Environment in Mountain Regions, IAHS 209 pp. 41-50, 2-4 July, Chengdu, China, 1992.

[19] Emmanouloudis D., Takos I., Spanos I., Evolution of the erosive process after a watershed fire: An example: Prinos torrent, Thassos island, Greece. Proceedings of 3rd International Conference: "Risk Analysis III", Eds. Brebbia C.A., Wessex Institute of Technology, WIT Press, ISBN: 185312-915-1, pp.265-276, England, 2002. 